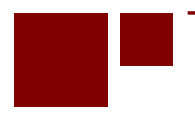

C E N T E R for RETIREMENT RESEARCH at BOSTON COLLEGE

\title{
SOCIAL SECURITY AND TOTAL REPLACEMENT RATES IN DISABILITY AND RETIREMENT
}

\author{
Mashfiqur R. Khan, Matthew S. Rutledge, and Geoffrey T. Sanzenbacher
}

CRR WP 2017-6

May 2017

Revised: May 2018

\author{
Center for Retirement Research at Boston College \\ Hovey House \\ 140 Commonwealth Avenue \\ Chestnut Hill, MA 02467 \\ Tel: 617-552-1762 Fax: 617-552-0191 \\ http://crr.bc.edu
}

Mashfiqur R. Khan is a doctoral candidate in economics at Boston College. Matthew S. Rutledge and Geoffrey T. Sanzenbacher are research economists at the Center for Retirement Research at Boston College. This research was supported by the U.S. Social Security Administration (SSA) through grant \#1 DRC12000002-04-00 to the National Bureau of Economic Research (NBER) as part of the SSA Disability Research Consortium. The findings and conclusions expressed are solely those of the authors and do not represent the views of SSA, any agency of the federal government, the NBER, or Boston College.

(C) 2018, Mashfiqur R. Khan, Matthew S. Rutledge, and Geoffrey T. Sanzenbacher. All rights reserved. Short sections of text, not to exceed two paragraphs, may be quoted without explicit permission provided that full credit, including $(\subset$ notice, is given to the source. 


\begin{abstract}
About the Center for Retirement Research
The Center for Retirement Research at Boston College, part of a consortium that includes parallel centers at the University of Michigan and the National Bureau of Economic Research, was established in 1998 through a grant from the Social Security Administration. The Center's mission is to produce first-class research and forge a strong link between the academic community and decision-makers in the public and private sectors around an issue of critical importance to the nation's future. To achieve this mission, the Center sponsors a wide variety of research projects, transmits new findings to a broad audience, trains new scholars, and broadens access to valuable data sources.
\end{abstract}

\author{
Center for Retirement Research at Boston College \\ Hovey House \\ 140 Commonwealth Ave \\ Chestnut Hill, MA 02467 \\ Tel: 617-552-1762 Fax: 617-552-0191 \\ http://crr.bc.edu
}

Affiliated Institutions:

The Brookings Institution

Syracuse University

Urban Institute 


\begin{abstract}
Social Security provides higher replacement rates to disability insurance beneficiaries than retired beneficiaries. This fact reflects two factors: 1) Disability Insurance (SSDI) beneficiaries have lower career earnings, and Social Security benefits are progressive; and 2) SSDI benefits are not reduced for claiming early. This project uses the 1992-2010 waves of the Health and Retirement Study (HRS) linked to Social Security Administration earnings records to decompose the differences between the Social Security replacement rates for retired worker and SSDI beneficiaries into these two factors. The project also examines how the total replacement rate - which accounts for other sources of income in addition to Social Security - differs between retirees and SSDI beneficiaries to capture the difference in overall retirement security between the two groups. The results indicate that about half of the 10-percentage-point advantage in Social Security replacement rates for SSDI beneficiaries is due to the actuarial adjustment applied to retirement benefits, implying that career earnings are not that different between retired workers and SSDI beneficiaries. But total replacement rates are substantially lower for SSDI beneficiaries, which indicates that, despite Social Security’s vital role in providing a reliable income source, SSDI beneficiaries have much lower post-career well-being than retired workers.
\end{abstract}




\section{Introduction}

The well-being of people who are no longer working depends crucially on the income they can derive from social insurance, other public programs, and their assets. The most commonly-used measure for whether individuals or households are prepared for those nonworking years is the replacement rate - the ratio of their post-work income to their income or earnings from their working years. This measure implicitly asserts that the benchmark for wellbeing in retirement or disability is their pre-retirement or pre-disability standard of living. Individuals or households who cannot maintain their previous income - after accounting for natural reductions in their needs from, e.g., lower tax burdens or decreased work-related expenses - will have to live on less. The required decrease in consumption may hurt their health, their ability to withstand shocks, and their enjoyment of their "golden years."

Social Security is a vital income source for retirees and persons with disabilities, and previous estimates indicate that Social Security fills much more of the income needs of Social Security Disability Insurance (SSDI) beneficiaries than for retirees. The typical SSDI beneficiary had a Social Security replacement rate - the ratio of their benefit to their careeraverage earnings - of just less than 60 percent in 2000 (SSA 2006). This figure is greater than the approximate 40-percent replacement rate for the typical retirement beneficiary at their actual claiming age around the same time (Munnell and Soto 2005).

The comparison of the two programs' replacement rates suggests that Social Security is more generous toward SSDI recipients than towards retirees. But this comparison masks the underlying reasons for the difference. To some extent, the greater generosity for disability beneficiaries is explicit in the structure of Social Security, as its benefit formula is progressive. Workers with disabilities tend to earn less over their careers, including a long decline that starts well before the official date of disability onset (Charles 2003; Meyer and Mok 2013), so they benefit more from the progressive benefit formula.

But the replacement rate comparison also reflects differences in how benefits are adjusted due to early claiming. The majority of retirement beneficiaries claim their benefits before their Full Retirement Age (FRA); such early claiming triggers an actuarial reduction, lowering benefits by as much as 25 percent - and soon to be 30 percent, when the FRA increases to age 67 starting with the 1960 cohort. SSDI beneficiaries, in contrast, receive the same benefit they would have received at their FRA, no matter when they first receive benefits. To isolate the 
effect of the actuarial reduction, this study compares the disability replacement rate to the replacement rate that retirees would have received at their FRA - that is, without the actuarial reduction. Any remaining difference is attributable to differences in career average earnings that is, from the progressivity of the benefit formula.

The comparison of replacement rates also misses another important point: the higher Social Security replacement rate does not imply that SSDI beneficiaries are better off than retirees. In fact, Social Security is practically the only source of post-career income for disability beneficiaries. On average, Social Security benefits makes up 86 percent of the personal income of SSDI beneficiaries, compared to 53 percent of the income of retirement beneficiaries. ${ }^{1}$ The progressive benefit formula allows lower-earning workers with disabilities to keep more of those earnings, but lower earnings also makes saving especially difficult. Low earners’ spotty employment history may also leave them without access to employer-sponsored retirement savings vehicles (Wu and Rutledge 2014). A better measure of the differences in retirement well-being between retirees and SSDI beneficiaries is the respective groups' total replacement rates, which account for other income sources like employer-sponsored retirement plans and private saving.

This study uses the Health and Retirement Study linked to Social Security Administration earnings records to calculate replacement rates for retirement and SSDI beneficiaries. First, the analysis decomposes the difference in Social Security replacement rates at actual claiming dates for the respective programs into the amount attributable to differences in earnings and the portion attributable to the actuarial adjustment. Second, it compares the groups' total replacement rates to establish the differences in post-career well-being for retirees and SSDI beneficiaries. The results of this analysis will inform the debate about the impact of Social Security on the financial security of its beneficiaries, accounting for the heterogeneity between retirees and SSDI beneficiaries.

The results indicate that the difference in Social Security replacement rates between disability and retired worker beneficiaries is only about 10 percentage points, and half of that difference is due to the actuarial reduction of benefits. After accounting for this adjustment, therefore, average career earnings are not that different for retirees and SSDI beneficiaries, with the exception of married women.

\footnotetext{
${ }^{1}$ Authors' calculations from the HRS sample used in this study.
} 
But SSDI beneficiaries have much lower total replacement rates, in large part because they lack any other source of post-career income. The disadvantage that SSDI beneficiaries face relative to retired worker beneficiaries also grows with earnings - workers with disabilities in the highest quintile of career earnings have total replacement rates that are nearly double the total replacement rates of similar-earning retirees.

The paper is organized as follows. The second section outlines the differences between Social Security retirement and disability benefits, in their eligibility, benefit calculation, and incentives to apply at particular ages. The third section describes the existing literature on Social Security and total replacement rates. The fourth section describes the HRS data and outlines the empirical strategy. The fifth section describes results, and the sixth section concludes that, despite the positive and important role that Social Security plays in providing disability beneficiaries a reliable later-life income source, post-career well-being is much lower for SSDI beneficiaries than for retired workers.

\section{Comparing Social Security Disability and Retirement Benefits}

The analysis in this paper focuses on two aspects of the Social Security program that are designed to provide benefits to individuals who are no longer working. One is Old Age and Survivors Insurance (OASI), which pays out retirement benefits. The other is Social Security Disability Insurance (SSDI), which pays out benefits to workers with disabilities.

Workers are eligible for Social Security benefits after accumulating a sufficient number of years in covered employment - that is, earning income that is subject to Social Security taxes. Retired workers need to accumulate 40 quarters of coverage, or credits, over their careers. They add a quarter of coverage for each multiple of \$1,260 (in 2016 dollars) of annual earnings, up to 4 credits per year; essentially, they need the equivalent of ten substantial years of covered employment. Potential SSDI applicants need to accumulate one credit for every year since age 22 (inclusive), as well as 20 credits in the most recent 10 years. $^{2}$

Retirement benefit entitlement is based solely on experience and age: workers may collect benefits starting at age 62 if they have already accumulated the required quarters of

\footnotetext{
${ }^{2}$ Workers younger than 31 require at least 6 credits, as well as credits in at least one-half of the calendar quarters beginning with the first full quarter after they turned 21. Our sample is limited to individuals receiving disability benefits in their 50s, however.
} 
coverage. Disability entitlement also depends on experience, but further requires an evaluation to determine whether the worker's medical conditions will result in his death or limit his ability to work for at least one year, as well as completing a five-month waiting period after disability onset. $^{3}$

Both retirement and disability benefits are based on workers' typical earnings over the course of their career. The first step for either program is calculating the Average Indexed Monthly Earnings (AIME). For retirement benefits, the AIME is the average of the top 35 years of earnings (adjusting for wage inflation), divided by 12. For SSDI, the average is based on a smaller number of “computation years” to account for disability applicants' shorter careers. ${ }^{4}$ Workers may have low AIMEs because their earnings in their highest-earning years were low, or because they earned wages in covered employment for fewer than the proscribed number of countable years - zeroes are added as necessary, which lowers their AIME. Workers with disabilities are vulnerable to both of these phenomena; their health limits their ability to earn substantial amounts when they are working, and may limit their ability to work entirely in other years. Furthermore, self-selection may result in lower AIMEs for workers with disabilities: Autor and Duggan (2006) find that workers with lower earning potential - for example, the lesseducated, or workers in economic downturns - are more likely to apply for disability.

The next step to calculate benefits in both programs is determining the Primary Insurance Amount (PIA), based on a progressive benefit formula. The PIA is equal to 90 percent of the worker’s first \$856 of AIME, plus 32 percent of the AIME between \$856 and \$5,157, plus 15 percent of the remaining AIME (all figures in 2016 dollars). The Social Security replacement rate for workers with low AIMEs, therefore, could be as high as 90 percent, but most AIMEs fall in the 32-percent marginal range, so PIAs are usually between 32 and 90 percent of a worker's AIME. To the extent workers with disabilities have lower AIMEs than retired workers, this progressivity implies they will have higher Social Security replacement rates.

\footnotetext{
${ }^{3}$ Disability applicants are evaluated based on whether their medical conditions prevent them from Substantial Gainful Activity, defined as earning at least \$1,130 per month in 2016.

4 The number of computation years is equal to the number of years since turning 22, inclusive ("elapsed years”), minus the higher of 1) one-fifth of the elapsed years, or 2) five years. For example, a disability awardee who is 42 years old has 21 elapsed years $(42-22+1)$. One-fifth of 21 years is 4.2 years; the formula calls for truncating the fraction, so 4 out of the 21 years are ignored. Therefore, the awardee has 17 computation years - i.e., the awardee's benefit is based on the $21-4=17$ highest-earning years. The top 17 years can occur at any age.
} 
The main difference between how retirement and disability benefits are calculated is in the actuarial adjustment. SSDI beneficiaries receive their full PIA regardless of the age at which they first receive benefits. Retirement beneficiaries, however, have their benefits adjusted to account for their age at claiming. Retired workers' benefits are exactly equal to their full PIA only if they first receive benefits in the month in which they reach their FRA. Otherwise, retirement benefits are actuarially adjusted - that is, set to yield equal expected lifetime benefits no matter when they are first received. If retirees choose to receive benefits early, their benefits are adjusted downward by more for each month that the claim was earlier than the FRA. ${ }^{5}$ Later claiming results in larger benefits.

Individuals may apply for disability benefits up to their FRA, and the fact that disability benefits - unlike retirement benefits - are not subject to actuarial reduction makes disability application quite valuable to individuals who are too unhealthy to keep working. In practice, however, the application rate falls off quickly after retirement benefits become available at age 62, which suggests that the pecuniary and non-pecuniary costs of disability application substantially exceed the (minimal) costs of claiming retirement benefits (Rutledge 2012).

The analysis in this study focuses on SSDI, and not Supplemental Security Income (SSI), another program administered by SSA that pays benefits to low-income, low-asset individuals over 65 or with a work-limiting disability. SSI uses the same process for evaluating the severity and duration of individuals' disability as SSDI, and about one-half of SSDI beneficiaries also receive SSI. But whereas SSDI is social insurance, and its income-eligibility and benefit calculations are similar to OASI's parameters, SSI bases its income-eligibility and benefits on current income, with no requirement that recipients contributed to the system for a minimum amount of time. Therefore, comparisons between SSI and OASI are less informative, and the population receiving the respective benefits are less similar than the SSDI and OASI groups. So the analysis excludes anyone who is eligible only for SSI, though it does account for SSI income for any SSDI beneficiaries whose incomes are low enough to qualify for SSI.

\footnotetext{
${ }^{5}$ Benefits are reduced by 5/9 of one percent times the number of months between claiming and the FRA, if claiming was no more than 36 months early; if benefits were claimed more than 36 months early, benefits are reduced by 5/12 of one percent per month up to where the 36-month period begins.
} 


\section{Previous Literature}

The idea of using replacement rates as a measure of retirement well-being stems from the life-cycle model, which posits that individuals and households aim for a smooth consumption pattern over their lifetimes (Modigliani and Brumberg 1954). ${ }^{6}$ Of course, incomes fall in retirement, but consumption can stay constant because expenses fall. Non-workers do not have to pay Social Security and Medicare payroll taxes, and their personal income tax rate may also fall. Additionally, households who have reached the dissaving portion of the life cycle do not need to reserve a portion of their income for saving. And other expenses may fall, including transportation, clothing, and the costs incurred during a job search.

While researchers agree that post-retirement income can fall below pre-retirement income, studies use different target replacement rates based on their interpretation of the data and theoretical assumptions. The Georgia State RETIRE Project bases its targets on detailed study of consumption data for respondents at different earnings levels, by gender, and by the number of earners in the household (Palmer 2008). The targets range from 94 percent for 2-earner households making only \$20,000 in 2008 to 70 percent for unmarried earners making \$90,000. The National Retirement Risk Index (NRRI), updated regularly by the Center for Retirement Research at Boston College, adjusts these targets by adding housing wealth and defined benefit pensions, but the targets' range is similar: from 67 percent for a household with two higher earners to 85 percent for a married couple with one low-earning worker (Munnell, Webb, and Delorme 2006). Scholz and Seshadri (2009) base their target replacement rates on a life-cycle model that, unlike the NRRI, assumes that optimal consumption decreases with age and when the children leave home; as a result, their targets are lower - around 75 percent for married couples, but only 55 percent for singles.

Whether households can reach these targets depend on their retirement income sources. The primary source for many households is Social Security. SSA actuaries regularly update Social Security replacement rate projections for hypothetical workers at five different earnings levels and at three different claiming ages (62, 65, and the FRA); the “medium earner," whose earnings are consistently around \$48,000 (2016 dollars) throughout his career, receives about 41

\footnotetext{
${ }^{6}$ Munnell and Soto (2005) point out that, more precisely, agents aim to smooth their utility, and consumption is only one input into their utility function. The other is leisure, so when retirement increases their allotment of leisure, consumption can fall even while maintaining the same utility level. The consumption-leisure trade-off further justifies a target replacement rate substantially below one.
} 
percent of his pre-retirement earnings (Clingman, Burkhalter, and Chaplain 2016). Munnell and Soto (2005) find slightly lower Social Security replacement rates when they use actual earnings histories, which better reflect earnings volatility and the age-earnings profile. Biggs, Pang, and Schieber (2015) calculate slightly higher replacement rates because their denominator uses recent earnings rather than career average earnings; they contend that retirees are most interested in upholding their recent standard of living rather than over their full career. The analysis in this study focuses on career average earnings to more closely match the analysis of SSA actuaries; furthermore, using recent earnings can overstate replacement rates for persons with disabilities (who were not part of the Biggs, Pang, and Schieber analysis) who have seen their earnings fall well before the official onset date.

Of course, retirement well-being depends on all income sources, not just Social Security. Munnell and Soto (2005) build the total replacement rate from Social Security, pension income, and other financial assets, including the house. Their total replacement rate reaches over 80 percent for households with retirement plan coverage, but in households with no retirement plans, total replacement rates fall well short of targets. ${ }^{7}$ The latest NRRI update projects that 52 percent of working households will see their total replacement rates fall short of targets, especially young workers and low-income households (Munnell, Hou, and Webb 2014). Butrica, Smith, and Iams (2012) project that the median total replacement rate is likely to fall from 98 percent for the pre-war birth cohort to 84 percent for Generation X (1966-1975), and that 43 percent of Gen-Xers will fall short of their target. These pessimistic projections differ from studies such as Scholz, Seshadri, and Khitatrakun (2006), who find only 16 percent of households have insufficient wealth. But the more optimistic studies share the assumptions underlying the Scholz and Seshadri (2009) target replacement rates: declining optimal consumption with age, and a decrease in consumption when children leave the home. Munnell, Rutledge, and Webb (2014) show that differences between the studies in the proportion of people at risk of not being able to meet targets depends entirely on these assumptions, and argue that these assumptions are not well-justified empirically. ${ }^{8}$

\footnotetext{
${ }^{7}$ Munnell and Soto (2005) do not examine replacement rates for SSDI beneficiaries; that group is explicitly removed from their sample.

${ }^{8}$ For example, Dushi et al (2015) find that household consumption decreases by only a small, precisely-estimated share of income when children leave home - far less than the Scholz and Seshadri (2009) model assumes.
} 
Replacement rates are not a perfect measure of retirement well-being, however - if a household's income is always low, a high replacement rate may still leave them short of the poverty line. This concern is even more pertinent to households with a worker with a disability, whose incomes are generally lower throughout their lives. As a result, few studies focus on replacement rates for workers with disabilities, as other measures - such as whether postdisability income meets the poverty threshold - are better representations of well-being. ${ }^{9}$ Replacement rates are more likely to appear as part of research on disability as a measure of the incentives to apply for benefits. For example, Autor and Duggan $(2003,2006)$ cite rising SSDI replacement rates - from 35 percent in 1984 to 46 percent in 2002, among men ages 50-61 - as a major reason for the growth in SSDI application and receipt rates.

The fact that early retirees can earn a larger benefit if they apply for SSDI benefits is well-understood (e.g., see Benitez-Silva and Yin 2011 and Rutledge 2012). But outside of that financial incentive, the literature is largely silent on the direct comparison between Social Security disability and retirement benefits. Studies have also not focused on the differences in post-work well-being - as measured by the total replacement rate - between people leaving work for retirement versus disability. ${ }^{10}$ This study, therefore, fills a gap in the literature: laying out the differences between retirees and persons with disabilities in their well-being after they stop working; establishing the differences in how they benefit from Social Security vs. other income sources; and decomposing why their Social Security replacement rates differ.

\section{Data and Methodology}

This study uses the 1992-2012 waves of the HRS linked to the summary earnings records provided by SSA. The overall sample consists of individuals born in 1930 or later with valid earnings records who are "insured” for Social Security benefits - that is, having accumulated enough quarters of coverage over their careers to be income-eligible for either retirement or disability benefits. This sample is split into two subsamples, whose benefits and replacement rates are compared: 1 ) the SSDI sample, consisting of individuals who ever report receiving

\footnotetext{
${ }^{9}$ One of the rare exceptions is Muller and Lando (1980), which examined replacement rates from earnings for disabled men.

${ }^{10}$ Bound and Waidmann (2010) compare early retirees to disability beneficiaries, reweighting the former sample to look more like the latter. But their focus is on the extent to which raising the Early Entitlement Age would lead to increased disability applications, rather than on post-work well-being.
} 
disability benefits during their HRS sample window, ${ }^{11}$ and 2) the OASI sample, consisting of all other covered workers who reach their FRA within the sample window.

Social Security disability and retirement benefits are calculated for any hypothetical claiming age using the summary earnings records. Actual benefits, however, rely on self-reports of the timing of disability and retirement benefit claiming.

The outcome measures in this study are replacement rates: the ratio of post-retirement income to pre-retirement earnings. The first part of the analysis limits the analysis to Social Security replacement rates: the ratio of Social Security benefits to the pre-retirement earnings upon which those benefits are based. Most of the analysis uses the worker's AIME as the denominator in this ratio, though we also present analysis using a different denominator focused on the worker's late career: the top 5 out of the last 10 years (adjusted for inflation) before retirement or disability benefit receipt, as in Munnell and Soto (2005). Goss et al. (2014) find that, because OASI beneficiaries have fairly stable earnings, their replacement rates are relatively equal using AIME, peak earnings, or end-of-career earnings in the denominator. But SSDI beneficiaries' earnings typically decline well before they apply (Charles 2003; Meyer and Mok 2013), so the career average earnings measure may include many years of earnings that are lower than their pre-disability standard of living. Alternative denominators that use just the highest five years of earnings late in their career may lead to a different conclusion.

The aim of the first part of the analysis is to decompose the differences in Social Security replacement rates for OASI and SSDI beneficiaries into: 1) the difference due to career-average earnings; and 2) the difference due to actuarial adjustments. The first exercise simply compares the benefits-to-AIME ratio for each group based on their actual claiming experience. This exercise will confirm that replacement rates are higher in SSDI than in OASI. But the replacement rate is higher because of both earnings differences and the actuarial adjustment.

The second exercise compares SSDI replacement rates to the replacement rate that retirees would have received if they claimed at their FRA - that is, if they, like workers with disabilities, were to receive their full Primary Insurance Amount. By removing any difference

\footnotetext{
${ }^{11}$ HRS cannot reliably distinguish between SSI and SSDI receipt, but because these workers have enough quarters of coverage, they should all be receiving at least SSDI, if not both benefits concurrently. Anyone ineligible for SSDI is dropped from the sample, including SSI-only beneficiaries.
} 
due to the actuarial adjustment, the remaining difference in replacement rates is entirely due to differences in career-average earnings and the progressive benefit formula.

In addition, this part of the analysis also presents the hypothetical Social Security replacement rates if all retired workers had claimed benefits at age 62. Workers who are struggling with their health are most likely to claim retirement benefits at age 62 - that is, as early as possible - if they do not receive SSDI benefits; they are unlikely to hold out until the average claiming age for retired workers overall. This exercise, therefore, shows a more appropriate counterfactual replacement rate for disability beneficiaries.

The second aim of the project is to evaluate the extent to which the benefits-to-AIME ratio reflects the ability of beneficiaries to maintain their pre-retirement standard of living. Social Security replacement rates tell only part of the story. Retired workers, due to their higher earnings and more stable work patterns, are more likely to participate in retirement plans, accrue more retirement and housing wealth, and be able to avoid debt accumulation and withdrawing funds before retirement.

To account for these factors, the project uses the HRS to calculate the total replacement rate: the ratio of total retirement income to the AIME. Echoing Munnell and Soto (2005), the project adds to the numerator the actual (or projected) monthly income from defined benefit (DB) pensions, as well as the potential annuitized value of defined contribution (DC) plans and Individual Retirement Accounts (IRAs), less outstanding debt. ${ }^{12}$ Adding DB income is straightforward: we include each spouse's self-reported DB benefit - whether or not they have started receiving that benefit - in the wave closest to the age in question (actual claiming age, age 62, or FRA). ${ }^{13}$ DC income is more challenging, because HRS respondents report the balance in their 401(k)-style plans and their IRAs (most of which consist of rolled-over DC plans). To convert the stock measure of their DC wealth into a flow, we assume that participants annuitize their DC wealth at prevailing rates from Annuity Shopper (2015), using the methodology in Munnell et al (2016). Although few households annuitize their DC wealth, this measure provides a proxy for the withdrawals they could make from DC plans without exhausting their

\footnotetext{
12 Unlike Munnell and Soto (2005), this analysis does not include housing equity as an asset. It does, however, include outstanding mortgage debt as part of the liabilities subtracted from the numerator.

${ }^{13}$ Lump-sum DB distributions are converted to DB income using the same hypothetical annuitization process as DC wealth.
} 
wealth before their expected death date. ${ }^{14}$ Finally, the numerator includes SSI income for the lower-income individuals and households who appear to qualify. ${ }^{15}$

The analysis is conducted separately by gender to account for different patterns in career earnings for men and women. It is also conducted separately by AIME quintile, which is based on the earnings distribution for the retired worker sample. The Social Security replacement rate medians by AIME quintile will mostly follow the progressivity of the benefit formula. But the total replacement rate by AIME quintile will help determine the extent to which OASI beneficiaries' greater earnings account for the difference in total replacement rates between them and SSDI beneficiaries. A finding that the total replacement rate is lower for SSDI beneficiaries than for OASI beneficiaries with comparable career average earnings suggests that workers with disabilities are hurt by their volatile earnings histories (i.e., the variance of earnings, rather simply its lower levels), by differences in spending needs, or by differences in their taste for saving.

This study also presents individual replacement rates by marital status, and calculates replacement rates at the household level; both analyses aim to account for the likelihood that the total resources available to a married individual is not limited to his own Social Security benefits and retirement savings. One challenge in the household analysis is that spouses may not yet be eligible for their own Social Security benefits. SSDI beneficiaries, in particular, may have lower household resources because they may be only in their 50s, which means their spouses are often much younger than age 62. The spouses of retirement beneficiaries, in contrast, are likely close to age 62, if not older, so we are more likely to observe the household relying on both spouses' benefits. We calculate the spouses' potential benefits as of the beneficiary’s milestone age actual retirement age, 62, FRA, and actual SSDI application age - to reflect the benefits the spouses have already accrued. We then include results where the accrued benefits of spouses under age 62 are added to the numerator of the Social Security and total replacement rates.

\footnotetext{
${ }^{14}$ Because so few households annuitize, the results may overstate the differences in total replacement rates if retired workers or their households are intentionally less likely to spend down DC wealth, either because of a bequest motive or as precautionary saving for shocks (e.g., financing long term care). Still, this wealth is available to them if needed, and therefore needs to be accounted for in their potential resources.

${ }^{15}$ For the few individuals with total income below the maximum SSI benefit - \$733 in 2016 - we reset the numerator of the replacement rate to be that year's SSI maximum (because SSDI benefits replace SSI benefits dollar-for-dollar after the first $\$ 20$, the total disability benefit the beneficiary receives is the SSI maximum). This calculation implicitly ignores the asset test for SSI eligibility. While few men fall below the SSI threshold (less than 5 percent of our sample), 28 percent of women in our SSDI sample have total income below the maximum SSI benefit.
} 
Furthermore, the project examines how each replacement rate has changed over time, reflecting the aging of the workforce and the changing composition of SSDI beneficiaries.

\section{Results}

Social Security Replacement Rates. Table 1 presents the median and mean individual replacement rates from Social Security income for the full sample, and separately by gender. In our sample, retirement beneficiaries receive a median of 40 percent of their average career earnings from Social Security at their actual claiming age, and a mean of 44 percent.

In contrast, SSDI beneficiaries receive a median replacement rate of 50 percent. ${ }^{16}$ This figure is smaller than the replacement rate reported in SSA (2006) for SSDI beneficiaries in 2000, which may reflect rising career earnings among SSDI beneficiaries as receipt rates have increased. The SSDI replacement rate is 10 percentage points higher than retirement beneficiaries receive (at their actual claiming ages), though some of that difference is explained by the actuarial adjustment. Without that adjustment - that is, at FRA, when retired workers receive their full PIA - the difference in replacement rates is half as large: only 5 percentage points.

The other noteworthy comparison is to retirement benefits at age 62 because, without SSDI, most workers with disabilities would likely claim retirement benefits as early as possible. The actual replacement rate for SSDI beneficiaries is 14 percentage points greater than the replacement rate if all retirement beneficiaries had retired at age 62 and been forced to take the actuarial reduction.

Male retirees receive a median of 36 percent of their career earnings at their actual claiming ages, compared to 44 percent for male SSDI beneficiaries. ${ }^{17}$ Without the actuarial adjustment, however, the replacement rate is only 2 percentage points larger for workers with disabilities. For women, the median replacement rate from retirement benefits (at the actual claiming ages) is 45 percent, or 51 percent at the Full Retirement Age; by both measures, the gap with the replacement rate of disabled women (58 percent) is greater.

\footnotetext{
${ }^{16}$ SSI-only beneficiaries (not shown) have a median replacement rate of 90 percent, with a mean of 83 percent. 17 The mean replacement rate is closer to the median for men than for women. This result could arise because men are less likely to have the low career earnings levels that result in high replacement rates.
} 
Total Replacement Rates. Table 2 reports the individual replacement rates based on income not just from Social Security, but from all post-career income sources. In contrast to Social Security replacement rates, which favor SSDI recipients because of their low earnings, total replacement rates are substantially higher for retired worker beneficiaries. Retirees are able to draw on as much as 75 percent of their pre-retirement earnings at their actual retirement age, compared to only 59 percent for SSDI beneficiaries, a 16-percentage-point gap.

The total replacement rate at the actual retirement age is lower than it could be, however, because retirement benefits are reduced for early claiming; without that adjustment, the total replacement rate is 82 percent, or 23 percentage points greater than for SSDI beneficiaries. Moreover, even if all retirees claimed benefits at age 62, they would still have a 9-percentagepoint advantage of SSDI beneficiaries.

The gap in the median total replacement rates between retired workers and SSDI beneficiaries is greater for men than for women. Among men, the total replacement rate is 73 percent at the actual retirement age, 23 percentage points more than the total replacement rate for SSDI beneficiaries; without the actuarial adjustment, the gap is 28 percentage points. For women, retired workers draw 77 percent of their pre-retirement earnings from all sources (at their actual claiming ages), compared to 68 percent for disabled women, a 9-percentage-point gap. But women's early claiming masks the underlying gap in their PIAs: if all female retirement beneficiaries claimed at their FRA, their total replacement rates would be 18 percentage points greater than total replacement rates for workers with disabilities.

Table 3 reports the median Social Security and total replacement rates for each quintile of career average earnings. ${ }^{18}$ Not surprisingly, lower earners benefit most from Social Security, relative to their pre-retirement earnings. The Social Security replacement rate for retirees at their actual claiming age declines monotonically from 69 percent for the lowest quintile to 31 percent for the top quintile. The decline is even steeper for SSDI beneficiaries, from 81 percent to 35 percent, though the sample size of SSDI recipients in the highest quintile is small. ${ }^{19}$ Within each

\footnotetext{
18 This analysis differs from the replacement rates calculated by Clingman, Burkhalter, and Chaplain (2016); that report simulates replacement rates for hypothetical workers by earnings level, but assumes that their earnings are constant throughout their careers. Instead, our empirical analysis allows workers' earnings to vary, and then categorizes workers by their career average earnings level. Munnell and Soto (2005) dissect the differences between the hypothetical worker projections and actual HRS respondents in great detail.

${ }^{19}$ To facilitate comparisons between the two groups of beneficiaries, the quintile thresholds are set for the retired worker sample, but applied to both retirees and disability beneficiaries. As a result, the sample size for workers with
} 
quintile, the difference between the median Social Security replacement rates for retired workers (at their actual claiming age) and workers with disabilities gets progressively smaller: from a 12percentage-point gap in the lowest quintile to only a 4-percentage-point gap in the highest quintile. The groups have similar earnings within these categories, by construction, so the replacement rate at the FRA for retirees is almost identical to the SSDI replacement rate in each quintile; therefore, the gap in replacement rates is due solely to the actuarial adjustment. Because the lowest quintile is most likely to claim benefits early, the gap is largest at that earnings level, and declines steadily as earnings increase.

Total replacement rates exhibit a different pattern. For retired workers, the lowest quintile and the highest quintile can both draw on about 90 percent of their pre-retirement earnings from all income sources, but the middle three quintiles have total replacement rates of 64-69 percent. The U-shape pattern derives from the high Social Security replacement rate on the low end of the earnings distribution, and the greater ability to save at high earnings levels. The actuarial adjustment takes the largest bite out of the middle quintiles, as well: the total replacement rates are 5-7 percentage points greater if everyone in the middle three quintiles retired at the FRA instead of their actual retirement age, compared to a difference of only 3-4 percentage points for the top and bottom quintiles.

The replacement rates in the lower panel of Table 3 emphasize the importance of Social Security benefits. Workers with disabilities do not exhibit the same U-shape pattern as retirees: the total replacement rate is much higher in the lowest quintile, but is roughly equal in the other four quintiles, at around 50 percent. The total replacement rate is noticeably greater than the Social Security replacement rate for workers with disabilities in the top quintile - 52 percent of past earnings in total, with only 35 percentage points coming from Social Security - but that group is the exception. In other quintiles among SSDI beneficiaries, the Social Security and total replacement rates are almost equal; worse, the Social Security replacement rate is actually greater than the total replacement rate for SSDI beneficiaries in the bottom quintile, because only the total replacement rate accounts for outstanding debt.

Furthermore, the gap in total replacement rates between retirees and SSDI beneficiaries grows with earnings, especially after removing the actuarial adjustment: from 4 percentage

disabilities is largest in the lowest quintile (313 observations) and less than half as large in the highest quintile (147 observations). 
points in the lowest quintile to 39 percentage points for the highest quintile. These results indicate that SSDI beneficiaries have much less access to post-career income than retirees, and that this disadvantage widens as Social Security benefits become more limited at higher earnings levels.

Table 4 report the median replacement rates by marital status, separately by gender. The gap between the Social Security replacement rates of retirees and disability beneficiaries is small for single and married men and single women, after accounting for the actuarial adjustment. But the gap is larger for married women, even among those who are not drawing spousal benefits (women receiving any spousal benefit are excluded from Table 4). The replacement rate from OASI benefits is 15 percentage points lower than from SSDI benefits, and only one-third of that difference is explained by the actuarial adjustment; married women on disability have earnings that are just that much lower than the earnings of married women receiving retirement benefits.

Men have a greater difference in the total replacement rate between SSDI beneficiaries and retirees: after removing the actuarial adjustment, single men's total replacement rates in retirement are 31 percentage points larger than for disability, compared to a 19-percentage-point gap for single women. The difference in these gaps is about the same for married men, relative to married women.

Household Replacement Rates. The above analysis considers retirement and disability beneficiaries independent of their family resources, but Social Security beneficiaries from either program likely share resources with their spouses. Tables 5 and 6 report household replacement rates - that is, the ratio of a married couple's total post-career Social Security income or total income relative to the sum of the couple's AIMEs. The left panel of each table does not include younger spouses' accrued benefit in the numerator of the replacement rates; the right panel does include their accrued benefit.

The first row of Table 5 indicates that the Social Security replacement rate is slightly higher for SSDI beneficiaries (43 percent) than what retired workers receive at their actual claiming age (38 percent). Of course, many retirees have their benefits reduced by the actuarial adjustment; if they were all to retire at their FRA instead, the household Social Security replacement rate would be slightly larger for retirees (45 percent) than for disability beneficiaries. The difference between the OASI replacement rate at FRA and the SSDI replacement rate is largest for couples where the secondary earner is eligible for some of her own 
benefit and also receives some spousal benefits ("1.5-earner couples," in the fourth row) but, curiously, larger for 2-earner couples than for married couples with only one earner. This surprising results appears to be due to spouses who are not yet age-eligible for Social Security; once these spouses' own benefits are added to the household Social Security income (right panel), the differences between Social Security replacement rates at the FRA and at actual SSDI claiming are small for all marital groups.

The bottom panel indicates that SSDI beneficiaries are at a substantial disadvantage in their total replacement rates. For the full sample, the household total replacement rate is 76 percent, or 84 percent after removing the actuarial adjustment, which is 23 percentage points greater than the total replacement rate for SSDI beneficiaries. The gap between the total replacement rates for retirees and disability beneficiaries is widest for 1-earner couples, who are more likely to have spouses' benefits available, but also over 30 percentage points for 1.5- and 2earner couples. Accounting for younger spouses' future Social Security benefits reduces this gap only modestly (right panel).

Importantly, Table 5 indicates that accounting for spouses' retirement benefits and other income are more likely to help retirees. For retirement beneficiaries overall (the first row), the total replacement rates at the household level are about 6 percentage points higher than the individual total replacement rates in Tables 1-2. In contrast, the total replacement rate is actually slightly lower at the household level for disability beneficiaries, indicating that spouses are not able to pick up the slack for the early end to their careers.

Table 6 splits the sample by AIME quintile. As observed at the individual level (Table 3), the difference between Social Security and total replacement rates at the household level is small for the lowest career earnings quintile (top row). But even among this disadvantage group, the difference between Social Security and total replacement rates are especially small for households with a disability beneficiary. The total replacement rate is only 5-6 percentage points (depending on the treatment of younger spouses' benefits) than the Social Security replacement rate for SSDI beneficiaries. Low-earning retirees, on the other hand, have total replacement rates that are 17-21 percentage points higher than their Social Security replacement rates, so they are able to draw on other household resources.

Moreover, household total replacement rates are far lower for SSDI beneficiaries than for retirees, and this difference widens with earnings: from 14 percentage points lower than retirees 
in the lowest quintile, to 45 percentage points in the highest quintile (though only a small group of SSDI beneficiaries are in this quintile). Whereas higher-earning retirees have potential household income similar to their pre-retirement income (i.e., replacement rates near 1), SSDI beneficiaries fall far short of typical target replacement rates in the 70-80 percent range.

Changes in Replacement Rates over Time. Table 7 reports median replacement rates for three time periods: the long expansion of 1992-2000; the mild recession and weak recovery of 2002-2006; and the Great Recession and its immediate aftermath, 2008-2012. Despite the differences in macroeconomic strength, as well as the aging of the Baby Boomers and the change in the composition of disability applicants (Liebman 2015), the replacement rates are similar over time. Individual and household Social Security replacement rates are essentially unchanged. Both individual and household total replacement rates were only a few percentage points lower during the Great Recession for retirees; while SSDI beneficiaries’ individual total replacement rates fell by 10 percentage points from 2002-2006 to 2008-2012, household replacement rates appear unchanged.

Robustness Check: Using Late-Career Earnings. Another replacement rate often used in analyses is constructed with a measure of late-career earnings in the denominator, to reflect the idea that retirees, especially, are attempting to replicate their recent lifestyle, not their average standard of living over many years (Biggs, Pang, and Schieber 2015). The recent standard of living for workers with disabilities often include years of lower earnings as health declines, so the replacement rate with career average earnings as the baseline seems more relevant for that group. For completeness, Table 8 presents median replacement rates with an alternative denominator: the highest five of the last ten years of earnings (as in Munnell and Soto 2005).

The pattern of replacement rates is similar - Social Security replacement rates are lower for retired workers than for disability beneficiaries, but total replacement rates are higher. But most of the replacement rates are lower by about 7-10 percentage points, because the denominator is larger; Munnell and Soto (2005) also find a difference of about 10 percentage points. The two exceptions are the household replacement rates for SSDI beneficiaries: their new replacement rates noticeably larger than the household replacement rates calculated with the AIME as the denominator. These latter two results likely derive from the long decline in earnings even before the official disability onset date, which makes late-career earnings lower for SSDI beneficiaries than their average earnings over their full careers. 


\section{Conclusion}

Social Security is an important source of income for retirees and, especially, persons with disabilities. This study examines the differences between retired workers and SSDI beneficiaries in their ability to maintain their standard of living after they stop working, and how Social Security contributes to this difference.

The study first compares Social Security replacement rates for retirees and disability beneficiaries. SSDI beneficiaries are better able to enjoy the fruits of their Social Security contributions for two reasons. First, the progressive structure of Social Security benefits allows for disability beneficiaries - who generally have lower earnings - to receive benefits that make up a greater proportion of their previous earnings than retirees. But even workers with identical work histories will draw greater benefits out of disability because, unlike with SSDI, early retirees face an actuarial reduction. This study finds that Social Security replacement rates are about 10 percentage points higher for SSDI beneficiaries than for retired workers. About half of that difference is due to the actuarial adjustment, leaving SSDI beneficiaries with only a small advantage over retirement beneficiaries.

When it comes to post-career well-being, however, Social Security replacement rates are only part of the story. The study also compares total replacement rates - the share of previous earnings that retirees or workers with disabilities are able to draw from all income sources. Despite the advantage that Social Security's progressivity gives to workers with disabilities, their total replacement rates are substantially lower than retired workers'. SSDI beneficiaries have few other sources of post-career income, even when the level of their previous earnings had been high; as a result, their total replacement rates are not much more than their replacement rates from Social Security alone. The lack of non-Social Security income opens up a gap with retirees that grows especially wide at the highest earnings levels: after accounting for the actuarial adjustment, Social Security retirement beneficiaries in the highest earning quintile have a total replacement rate nearly double that of SSDI beneficiaries in the same quintile.

Moreover, the study finds that SSDI beneficiaries fall even further behind retirees because their spouses are less able to provide a backstop. The differences in household total replacement rates between retirees and SSDI beneficiaries are even greater than for individual replacement rates. 
These results indicate that SSDI beneficiaries are at a substantial disadvantage to retired workers in their post-career well-being, even though their career earnings histories suggest that the groups do not differ that much (except among married women). Social Security benefits help to reduce these differences, but they can only do so much. These differences may arise because SSDI beneficiaries are less able to save during the careers, due to lower or more inconsistent earnings, or less access to employer-sponsored retirement plans. They may also arise because SSDI beneficiaries' long, slow decline in health and earnings eats away at their savings. The extent to which these factors contribute to the differences in well-being identified in this study are worth further exploration.

The difference in even the more-comprehensive total replacement rate measure may also understate the extent to which SSDI beneficiaries are at a disadvantage in their post-career wellbeing. The replacement rate measure is predicated on the notion that individuals and households who are no longer in the workforce want to maintain the standard of living to which they were accustomed while they were working. But SSDI beneficiaries start from a lower level of earnings, and have lower income more generally. Simply maintaining this too-low level may not be sufficient to support a comfortable, happy existence - or even the existence they knew before disability onset. Moreover, because this group, by definition, is less healthy, their health care costs are almost certainly greater. Their greater post-career consumption needs suggest aiming for a higher target replacement rate for this group than for retirees. The results of this study indicate that SSDI beneficiaries cannot hit even a lower target, so they would benefit from any reforms that increased SSDI generosity, thereby allowing persons with disabilities to more closely match the post-career lifestyles of retirees. 


\section{References}

Annuity Shopper. 2016. Annuity Shopper Buyer's Guide 31(1). Englishtown, NJ. Available at: https://www.immediateannuities.com/annuity-shopper/.

Autor, David H. and Mark G. Duggan. 2003. "The Rise in the Disability Rolls and the Decline in Unemployment.” Quarterly Journal of Economics 118(1): 157-206.

. 2006. "The Growth in the Social Security Disability Rolls: A Fiscal Crisis Unfolding.” Journal of Economic Perspectives 20(3): 71-96.

Benitez-Silva, Hugo and Na Yin. 2011. "Disability Insurance Applications near Retirement Age.” Working Paper. Stony Brook, NY: State University of New York at Stony Brook.

Biggs, Andrew G., Gaobo Pang, and Sylvester J. Schieber. 2015. "Measuring and Communicating Social Security Earnings Replacement Rates.” Working Paper 2015-01. Washington, DC: American Enterprise Institute.

Bound, John and Timothy Waidmann. 2010. “The Social Security Early Retirement Benefit as Safety Net.” Working Paper 2010-240. Ann Arbor, MI: Michigan Retirement Research Center.

Butrica, Barbara A., Karen E. Smith, and Howard M. Iams. 2012. “This Is Not Your Parents' Retirement: Comparing Retirement Income Across Generations.” Social Security Bulletin 72(1): 37-58.

Charles, Kerwin Kofi. 2003. "The Longitudinal Structure of Earnings Losses among WorkLimited Disabled Workers.” Journal of Human Resources 38(3): 618-646.

Clingman, Michael, Kyle Burkhalter, and Chris Chaplain. 2016. "Replacement Rates for Hypothetical Retired Workers.” Actuarial Note 2016.9. Washington, DC: U.S. Social Security Administration, Office of the Chief Actuary.

Dushi, Irena, Alicia H. Munnell, Geoffrey T. Sanzenbacher, and Anthony Webb. 2015. "Do Households Increase Their Savings When the Kids Leave Home?” Working Paper 201526. Chestnut Hill, MA: Center for Retirement Research at Boston College.

Goss, Stephen, Michael Clingman, Alice Wade, and Karen Glenn. 2014. "Replacement Rates for Retirees: What Makes Sense for Planning and Evaluation?” Actuarial Note 155. Washington, DC: U.S. Social Security Administration, Office of the Chief Actuary.

Meyer, Bruce and Wallace K.C. Mok. 2013. “Disability, Earnings, Income and Consumption.” Working Paper 18869. Cambridge, MA: National Bureau of Economic Research. 
Modigliani, Franco and Richard Brumberg. 1954. "Utility Analysis and the Consumption Function: An Interpretation of the Cross-Section Data.” In Post-Keynesian Economics, edited by Kenneth Kurihara, 388-436. New Brunswick, NJ: Rutgers University Press.

Muller, L. Scott and Mordechai E. Lando. 1980. "Replacement of Earnings of the Disabled Under Social Security: Levels \& Trends 1969-75.” Research Report No. 53. Washington, DC: U.S. Social Security Administration, Office of Research and Statistics.

Munnell, Alicia H., Wenliang Hou, and Anthony Webb. 2014. “NRRI Update Shows Half Still Falling Short.” Issues in Brief 14-20. Chestnut Hill, MA: Center for Retirement Research at Boston College.

Munnell, Alicia H., Wenliang Hou, Anthony Webb, and Yinji Li. 2016. "Pension Participation, Wealth, and Income: 1992-2010.” Working Paper 2016-3. Chestnut Hill, MA: Center for Retirement Research at Boston College.

Munnell, Alicia H., Matthew S. Rutledge, and Anthony Webb. 2014. “Are Retirees Falling Short? Reconciling the Conflicting Evidence.” Working Paper 2014-16. Chestnut Hill, MA: Center for Retirement Research at Boston College.

Munnell, Alicia H. and Mauricio Soto. 2005. "What Replacement Rates Do Households Actually Experience in Retirement?” Working Paper 2005-10. Chestnut Hill, MA: Center for Retirement Research at Boston College.

Munnell, Alicia H., Anthony Webb, and Luke Delorme. 2006. "Retirements at Risk: A New National Retirement Risk Index.” Working Paper. Chestnut Hill, MA: Center for Retirement Research at Boston College.

Palmer, Bruce A. 2008. 2008 GSU/Aon RETIRE Project Report. Atlanta, Georgia: Center for Risk Management and Insurance Research at Georgia State University.

Rutledge, Matthew S. 2012. "Holding Out or Opting Out? Deciding Between Retirement and Disability Applications in Recessions.” Working Paper 2012-26. Chestnut Hill, MA: Center for Retirement Research at Boston College.

Scholz, John Karl and Ananth Seshadri. 2009. "What Replacement Rates Should Households Use?” Working Paper 2009-214. Ann Arbor, MI: University of Michigan Retirement Research Center.

Scholz, John Karl, Ananth Seshadri, and Surachai Khitatrakun. 2006. "Are Americans Saving 'Optimally' for Retirement?” Journal of Political Economy 114(4): 607-643.

University of Michigan. Health and Retirement Study, 1992-2012. Ann Arbor, MI.

U.S. Social Security Administration. 2006. "Trends in the Social Security and Supplemental Security Income Disability Programs.” SSA Publication 13-11831. Washington, DC. 
Wu, April Yanyuan and Matthew S. Rutledge. 2014. "Lower-Income Individuals Without Pensions: Who Misses Out and Why?” Working Paper 2014-2. Chestnut Hill, MA: Center for Retirement Research at Boston College. 
Table 1. Individual Social Security Replacement Rates by Gender

\begin{tabular}{lcccr}
\hline & Median & Mean & Std dev & N \\
\hline $\begin{array}{l}\text { Full sample } \\
\text { Retirement }\end{array}$ & & & & \\
$\quad$ Actual & 0.40 & 0.44 & 0.14 & 5,369 \\
$\quad$ Age 62 & 0.36 & 0.40 & 0.12 & 5,369 \\
$\quad$ FRA & 0.45 & 0.50 & 0.15 & 5,369 \\
Actual SSDI claim & 0.50 & 0.55 & 0.17 & 1,143 \\
& & & & \\
Men & & & & \\
Retirement & & & & \\
$\quad$ Actual & 0.36 & 0.39 & 0.12 & 3,103 \\
$\quad$ Age 62 & 0.33 & 0.36 & 0.10 & 3,103 \\
$\quad$ FRA & 0.42 & 0.45 & 0.13 & 3,103 \\
Actual SSDI claim & 0.44 & 0.48 & 0.14 & 531 \\
$\quad$ & & & & \\
Women & & & & \\
Retirement & & & & \\
$\quad$ Actual & 0.45 & 0.50 & 0.15 & 2,266 \\
Age 62 & 0.41 & 0.45 & 0.13 & 2,266 \\
$\quad$ FRA & 0.51 & 0.57 & 0.16 & 2,266 \\
Actual SSDI claim & 0.58 & 0.62 & 0.17 & 612 \\
\hline
\end{tabular}

Source: University of Michigan, Health and Retirement Study (HRS), 1992-2012. 
Table 2. Individual Total Replacement Rates by Gender

\begin{tabular}{lrrrr}
\hline & Median & Mean & Std dev & N \\
\hline $\begin{array}{l}\text { Full sample } \\
\text { Retirement }\end{array}$ & & & & \\
$\quad$ Actual & 0.75 & 1.39 & 7.76 & 5,023 \\
$\quad$ Age 62 & 0.68 & 1.22 & 3.00 & 5,023 \\
$\quad$ FRA & 0.82 & 1.37 & 2.82 & 5,023 \\
Actual SSDI claim & 0.59 & 0.77 & 0.57 & 862 \\
& & & & \\
Men & & & & \\
Retirement & & & & \\
$\quad$ Actual & 0.73 & 1.31 & 2.58 & 2,893 \\
$\quad$ Age 62 & 0.66 & 1.22 & 2.47 & 2,893 \\
$\quad$ FRA & 0.78 & 1.41 & 2.81 & 2,893 \\
Actual SSDI claim & 0.50 & 0.61 & 0.38 & 404 \\
$\quad$ & & & & \\
Women & & & & \\
Retirement & & & & \\
$\quad$ Actual & 0.77 & 1.49 & 11.54 & 2,130 \\
Age 62 & 0.71 & 1.21 & 3.61 & 2,130 \\
$\quad$ FRA & 0.86 & 1.32 & 2.82 & 2,130 \\
Actual SSDI claim & 0.68 & 0.91 & 0.67 & 458 \\
\hline
\end{tabular}

Source: 1992-2012 HRS. 
Table 3. Median Social Security and Total Replacement Rates by AIME Quintile

\begin{tabular}{lccccc}
\hline & Lowest & Second & Third & Fourth & Highest \\
\hline $\begin{array}{l}\text { Social Security RR } \\
\text { Retirement }\end{array}$ & & & & & \\
$\quad$ Actual & 0.69 & 0.47 & 0.39 & 0.35 & 0.31 \\
$\quad$ Age 62 & 0.67 & 0.43 & 0.36 & 0.33 & 0.28 \\
$\quad$ FRA & 0.81 & 0.54 & 0.46 & 0.42 & 0.35 \\
Actual SSDI claim & 0.81 & 0.55 & 0.47 & 0.42 & 0.35 \\
& & & & & \\
Total RR & & & & & \\
Retirement & & & & & \\
$\quad$ Actual & 0.90 & 0.64 & 0.65 & 0.69 & 0.88 \\
$\quad$ Age 62 & 0.78 & 0.55 & 0.56 & 0.64 & 0.79 \\
$\quad$ FRA & 0.94 & 0.69 & 0.69 & 0.76 & 0.91 \\
Actual SSDI claim & 0.90 & 0.55 & 0.49 & 0.48 & 0.52 \\
\hline
\end{tabular}

Source: 1992-2012 HRS.

Table 4. Median Social Security and Total Replacement Rates by Marital Status and Gender

\begin{tabular}{lcccc}
\hline & \multicolumn{2}{c}{ Not married } & \multicolumn{2}{c}{$\begin{array}{c}\text { Married, } \\
\text { own benefit only }\end{array}$} \\
\cline { 2 - 5 } & Men & Women & Men & Women \\
\hline Social Security $R R$ & & & & \\
Retirement & & & & \\
$\quad$ Actual & 0.38 & 0.47 & 0.35 & 0.45 \\
$\quad$ Age 62 & 0.35 & 0.42 & 0.33 & 0.40 \\
$\quad$ FRA & 0.44 & 0.53 & 0.42 & 0.50 \\
Actual SSDI claim & 0.46 & 0.54 & 0.43 & 0.60 \\
& & & & \\
Total RR & & & & \\
Retirement & & & & \\
$\quad$ Actual & 0.71 & 0.78 & 0.73 & 0.77 \\
$\quad$ Age 62 & 0.69 & 0.69 & 0.65 & 0.72 \\
$\quad$ FRA & 0.80 & 0.84 & 0.78 & 0.88 \\
Actual SSDI claim & 0.49 & 0.65 & 0.50 & 0.69 \\
\hline
\end{tabular}

Source: 1992-2012 HRS. 
Table 5. Median Household Replacement Rates by Number of Earners

\begin{tabular}{|c|c|c|c|c|c|c|c|c|}
\hline & \multicolumn{4}{|c|}{$\begin{array}{l}\text { Not including spouses' future } \\
\text { benefits }\end{array}$} & \multicolumn{4}{|c|}{$\begin{array}{l}\text { Including spouses' future } \\
\text { benefits }\end{array}$} \\
\hline & \multicolumn{3}{|c|}{ Retirement } & \multirow{2}{*}{$\begin{array}{l}\text { Actual } \\
\text { SSDI } \\
\text { claim }\end{array}$} & \multicolumn{3}{|c|}{ Retirement } & \multirow{2}{*}{$\begin{array}{l}\text { Actual } \\
\text { SSDI } \\
\text { claim }\end{array}$} \\
\hline & Actual & At 62 & At FRA & & Actual & At 62 & At FRA & \\
\hline \multicolumn{9}{|l|}{ Social Security RR } \\
\hline Full sample & 0.38 & 0.34 & 0.45 & 0.43 & 0.42 & 0.39 & 0.48 & 0.47 \\
\hline Not married & 0.44 & 0.39 & 0.48 & 0.51 & 0.44 & 0.39 & 0.49 & 0.51 \\
\hline 1 earner & 0.39 & 0.35 & 0.52 & 0.47 & 0.54 & 0.51 & 0.65 & 0.62 \\
\hline 1.5 earners & 0.36 & 0.30 & 0.46 & 0.33 & 0.43 & 0.39 & 0.49 & 0.45 \\
\hline 2 earners & 0.33 & 0.26 & 0.39 & 0.29 & 0.38 & 0.35 & 0.42 & 0.42 \\
\hline \multicolumn{9}{|l|}{ Total $R R$} \\
\hline Full sample & 0.76 & 0.69 & 0.84 & 0.51 & 0.81 & 0.74 & 0.88 & 0.58 \\
\hline Not married & 0.74 & 0.68 & 0.82 & 0.57 & 0.74 & 0.69 & 0.82 & 0.57 \\
\hline 1 earner & 0.95 & 0.86 & 1.10 & 0.57 & 1.12 & 1.03 & 1.26 & 0.71 \\
\hline 1.5 earners & 0.80 & 0.72 & 0.87 & 0.48 & 0.86 & 0.79 & 0.91 & 0.59 \\
\hline 2 earners & 0.72 & 0.63 & 0.78 & 0.44 & 0.78 & 0.71 & 0.83 & 0.55 \\
\hline
\end{tabular}

Note: "1.5 earners" sample consists of married couples where one spouse earns his own benefit, and the other has her own benefit topped-off by the spousal benefit.

Source: 1992-2012 HRS. 
Table 6. Median Household Replacement Rates by AIME Quintile

\begin{tabular}{|c|c|c|c|c|c|c|c|c|}
\hline & \multicolumn{4}{|c|}{ Not including spouses' future benefits } & \multicolumn{4}{|c|}{ Including spouses' future benefits } \\
\hline & \multicolumn{3}{|c|}{ Retirement } & \multirow{2}{*}{$\begin{array}{c}\text { Actual } \\
\text { SSDI } \\
\text { claim }\end{array}$} & \multicolumn{3}{|c|}{ Retirement } & \multirow{2}{*}{$\begin{array}{l}\text { Actual } \\
\text { SSDI } \\
\text { claim }\end{array}$} \\
\hline & Actual & At 62 & At FRA & & Actual & At 62 & At FRA & \\
\hline \multicolumn{9}{|c|}{ Social Security RR } \\
\hline Lowest & 0.57 & 0.52 & 0.66 & 0.63 & 0.60 & 0.57 & 0.69 & 0.71 \\
\hline Second & 0.40 & 0.36 & 0.46 & 0.45 & 0.45 & 0.39 & 0.49 & 0.49 \\
\hline Third & 0.33 & 0.31 & 0.42 & 0.37 & 0.42 & 0.40 & 0.49 & 0.44 \\
\hline Fourth & 0.30 & 0.26 & 0.42 & 0.30 & 0.38 & 0.36 & 0.44 & 0.40 \\
\hline Highest & 0.29 & 0.22 & 0.37 & 0.23 & 0.34 & 0.32 & 0.38 & 0.35 \\
\hline \multicolumn{9}{|l|}{ Total RR } \\
\hline Lowest & 0.78 & 0.71 & 0.89 & 0.69 & 0.79 & 0.72 & 0.90 & 0.76 \\
\hline Second & 0.71 & 0.62 & 0.76 & 0.48 & 0.75 & 0.67 & 0.79 & 0.54 \\
\hline Third & 0.72 & 0.66 & 0.77 & 0.45 & 0.78 & 0.73 & 0.83 & 0.51 \\
\hline Fourth & 0.75 & 0.67 & 0.83 & 0.45 & 0.81 & 0.76 & 0.87 & 0.57 \\
\hline Highest & 0.85 & 0.78 & 0.95 & 0.42 & 0.92 & 0.84 & 0.99 & 0.54 \\
\hline
\end{tabular}

Source: 1992-2012 HRS. 
Table 7. Median Replacement Rates by Period

\begin{tabular}{lccc}
\hline & $1992-2000$ & $2002-2006$ & $2008-2012$ \\
\hline $\begin{array}{l}\text { Individual } \\
\text { Social Security RR }\end{array}$ & & & \\
Retirement & & & \\
$\quad$ Actual & 0.40 & 0.39 & 0.42 \\
Age 62 & 0.36 & 0.35 & 0.34 \\
$\quad$ FRA & 0.45 & 0.45 & 0.45 \\
Actual SSDI claim & 0.49 & 0.50 & 0.51 \\
Total RR & & & \\
Retirement & & & \\
$\quad$ Actual & 0.77 & 0.72 & 0.73 \\
$\quad$ Age 62 & 0.70 & 0.67 & 0.61 \\
$\quad$ FRA & 0.84 & 0.81 & 0.78 \\
Actual SSDI claim & 0.60 & 0.64 & 0.54 \\
$\quad$ & & & \\
Household & & & \\
Social Security RR & & & \\
Retirement & & & \\
$\quad$ Actual & 0.43 & 0.41 & 0.42 \\
Age 62 & 0.40 & 0.36 & 0.34 \\
FRA & 0.50 & 0.47 & 0.45 \\
Actual SSDI claim & 0.46 & 0.45 & 0.49 \\
Total RR & & & \\
Retirement & & & 0.76 \\
$\quad$ Actual & 0.83 & 0.79 & 0.56 \\
Age 62 & 0.76 & 0.71 & \\
FRA & 0.90 & 0.85 & \\
Actual SSDI claim & 0.59 & 0.58 & \\
\hline
\end{tabular}

Note: The time period refers to the wave when the respondent first reported receiving disability or retirement benefits. Household replacement rates include spouses' future benefits in the numerator. Source: 1992-2012 HRS. 
Table 8. Median Replacement Rates, Using Alternative Denominator

\begin{tabular}{lcccc}
\hline & \multicolumn{2}{c}{ Individual } & \multicolumn{2}{c}{ Household } \\
\cline { 2 - 5 } & Alternative & Diff with & Alternative & Diff with \\
& RR & AIME RR & RR & AIME RR \\
\hline $\begin{array}{l}\text { Social Security RR } \\
\text { Retirement }\end{array}$ & & & & \\
$\quad$ Actual & 0.32 & -0.08 & 0.36 & -0.06 \\
$\quad$ Age 62 & 0.29 & -0.07 & 0.32 & -0.07 \\
$\quad$ FRA & 0.38 & -0.07 & 0.42 & -0.06 \\
Actual SSDI claim & 0.40 & -0.10 & 0.54 & 0.08 \\
& & & & \\
Total RR & & & & \\
Retirement & & & & \\
$\quad$ Actual & 0.63 & -0.12 & 0.73 & -0.08 \\
$\quad$ Age 62 & 0.57 & -0.11 & 0.65 & -0.09 \\
$\quad$ FRA & 0.71 & -0.11 & 0.79 & -0.09 \\
Actual SSDI claim & 0.50 & -0.09 & 0.76 & 0.18 \\
\hline
\end{tabular}

Note: Denominator is the top 5 CPI-indexed annual earnings levels out of the final ten years before retirement or disability. Household replacement rates include spouses' future benefits in the numerator.

Source: 1992-2012 HRS. 


\section{RECENT WORKING PAPERS FROM THE CENTER FOR RETIREMENT RESEARCH AT BOSTON COLLEGE}

An Experimental Analysis of Modifications to the Survivor Benefit Information within the Social Security Statement

Jeffrey Diebold and Susan Camilleri, May 2017

Actuarial Inputs and the Valuation of Public Pension Liabilities and Contribution

Requirements: A Simulation Approach

Gang Chen and David S. T. Matkin, May 2017

Why Are U.S. Households Claiming Social Security Later?

Wenliang Hou, Alicia H. Munnell, Geoffrey T. Sanzenbacher, and Yinji Li, April 2017

Rising Inequality in Life Expectancy by Socioeconomic Status

Geoffrey T. Sanzenbacher, Anthony Webb, Candace M. Cosgrove, and Natalia S. Orlova, April 2017

The Effect of Job Mobility on Retirement Timing by Education

Geoffrey T. Sanzenbacher, Steven A. Sass, and Christopher M. Gillis, February 2017

Would Reducing the Price of Employing an Older Worker Improve Labor Market Outcomes by Socioeconomic Status? Evidence from Health Insurance Premium Restrictions

Matthew S. Rutledge and Caroline V. Crawford, December 2016

The Impact of Massachusetts Health Insurance Reform on Labor Mobility

Norma B. Coe, Wenliang Hou, Alicia H. Munnell, Patrick J. Purcell, and Matthew S. Rutledge, December 2016

Work, Retirement, and Social Networks at Older Ages

Eleonora Patacchini and Gary V. Engelhardt, November 2016

Calculating Expected Social Security Benefits by Race, Education, and Claiming Age

Geoffrey T. Sanzenbacher and Jorge D. Ramos-Mercado, November 2016

Do Late-Career Wages Boost Social Security More for Women than Men?

Matthew S. Rutledge and John E. Lindner, November 2016

Cognitive Impairment and Social Security's Representative Payee Program

Anek Belbase and Geoffrey T. Sanzenbacher, November 2016

All working papers are available on the Center for Retirement Research website (http://crr.bc.edu) and can be requested by e-mail (crr@bc.edu) or phone (617-552-1762). 